\title{
Ecological niche comparison of two cohabiting species, the threatened moth Eriogaster catax and Eriogaster lanestris (Lepidoptera: Lasiocampidae) - relevance for their conservation
}

\author{
Cristian Sitar, Dragomir-Cosmin David, Iulia Muntean, Geanina Magdalena Iacob, \\ Angela Monica IonICĂ \& László RÁKOSY
}

\begin{abstract}
Summary: Eriogaster catax and E. lanestris (Lepidoptera: Lasiocampidae) are two cohabiting species with extremely isolated populations. The anthropic impact lead to a decrease in their distributional areas, which led to the inclusion of $E$. catax in Annexes II and IV of the Council Directive 92/43/EEC. There are few studies regarding the species in question, revealing the scarcity of data regarding their biology and ecology. Our study was conducted in a Natura 2000 protected area, Turda Gorge (Romania) where the two species are present in an agroecosystem used as a pasture, which is covered in patches of by their main host plants, Prunus spinosa and Crataegus spp. The present study provides important data which can be used for the species conservation of $E$. catax, and it reveals a series of similarities between E. catax and E. lanestris with regards to habitat preferences and ecological needs in choosing the oviposition site.
\end{abstract}

Keywords: Eriogaster catax, E. lanestris, ecological niche, oviposition strategy, protection, conservation

\section{Introduction}

Eriogaster catax (LinNAEUs, 1758) and E. lanestris (LinNaEus, 1758), (Lepidoptera: Lasiocampidae) are two cohabiting species (SAFIAN 2006), associated to seminatural and agricultural landscapes with shrubby vegetation (KADEJ et al. 2018).

They can be found in natural, seminatural and anthropic habitats, in bushy meadows, alongside forest edges, deciduous forests, hedges, roads, railroads and other human impacted habitats, as long as their host plants are available (HöTTINGER 2005; BAILLET 2013; BURY 2015).

As a consequence of traditional agricultural activities, landscapes with a highly diverse mosaic of habitats were formed (BEAUFoy 1998). Such landscapes are highly important to the fauna, serving as refuge or corridors for several species, including endangered ones, such as E. catax (Forman and BAUDRY 1984, DOVER and SPARKS 2000, ZeCHMEISTER et al. 2002, Wehling and DieKManN 2009, WUCZYŃSKI et al. 2011, 2014, KADEJ et al. 2018). Furthermore, this type of landscape is characterized by an increased biodiversity, which can be maintained by low-intensity land use practice (BIGNAL and McCracken 1996, Plieninger et al. 2006, Loos et al. 2014). However, intensification of agriculture has a strong negative impact on biodiversity and currently, (MATSON et al. 1997, TsCHARNTKE et al. 2005), half of Europe's total land surface is covered by agricultural land (HALADA et al. 2011). As a consequence, anthropic pressure by agriculture intensification has led to extreme isolation of populations of the two species, both in Romania and at European level. E. lanestris is a xero-thermophilic species (EBERT 1994; RuF et al. 2003), while E. catax is a xero-thermophilic or, by case, a thermo-hydrophilic species, having particular requirements regarding or concerning the habitat (De Freina 1996, Borges 2012, Bury 2015, MALKIEWICZ 2015, KADEJ et al. 2018). According to MALKIEwICZ (2015) the habitat requirements are the main drivers of the isolation degree over its entire geographical distribution area.

The world-wide distribution of the two species covers the Palearctic Region. The geographical distribution of E. catax ranges from the Iberian Peninsula (Northern Spain) to the Balkans (De FreINA 1996, Borges 2012, Baillet 2013; Bury 2015), up to the south of the Ural Mountains and Asia Minor (DE Freina and Witt 1987, De Freina 1996, Karsholt and RAzowski 1996, RuF et al. 2003, Borges 2012, BAILlET 2013, BURY 2015). Until presently, the species has not been recorded in the Mediterranean region (Borges 2012). The widely distributed $E$. lanestris is spread throughout Europe, excepting the tundra and Mediterranean regions, up to the northern Caucasus, Kazakhstan, southern Siberia, Central Yakutia and Amur basin. Thus, in some countries of Europe and Asia, there is a partial territorial overlap of the two species. 


\section{Materials and methods Field sampling}

The study was performed in an area situated in central Transylvania, in the upper part of the left slope of the Turda Gorges, Cluj County Romania, which is a natural reservation and part of the Natura 2000 Site Cheile Turzii - ROSCI0035 (Fig. 1).

As natural reservation, Turda Gorges is a renowned hot-spot of biodiversity, as a consequence of the interecosystemic effect (RÁKosY 1995, RÁKosY and VARGA 2006), comprising over 900 known species of vascular plants (NYÁRÁDY 1939; RÁKOSY 2001) and over 1350 species of lepidopterans (RÁKosy 2001). The plateau area of the Gorges consists in a meadow including numerous shrubs of $P$. spinosa, Crataegus spp. and Rosa spp., which ensure a suitable habitat for both E. catax and E. lanestris and also for other endangered species of butterflies, such as Colias myrmidone (RÁKosY 2001). Annual mean temperature in Turda Gorges is $8,2^{\circ} \mathrm{C}$ and the annual precipitation is $624 \mathrm{~mm}$ (data obtained from http://worldclim.org for coordinates N 46.542139 E 23.627389).

However, the plateau area is used by the locals as pasture for sheep and goats. Sheep husbandry is sustained by agricultural subsidy of the Ministry of Agriculture and Rural Development (http://www. apia.org.ro/).

In the study area, populations of the two species were identified by visual identification of nest clustering (Fig. 2), followed by their inventory, mapping and measuring. For mapping, a hand held Garmin GPSmap 62s with $\pm 2 \mathrm{~m}$ error was used. For each nest, the height from the soil level and the total height of the host plant were recorded. The types of host plant were identified and divided based on their solitary or grouped pattern, if the shrub clustering was greater than $4 \mathrm{~m}^{2}$.

The cardinal orientation of each location was determined by cardinal degrees for the following value intervals: $\mathrm{N}: 0-22.5$ and 337.5-360; NE: 22.567.5; E: 67.5-112.5; SE: 112.5-157.5; S: 157.5-202.5; SW: 202.5-247.5;W: 247.5-292.5; NW: 292.5-337.5. Due to height and conformation of the shrubs, the cardinal orientation of the slope where the shrub was present was taken into account, not that of the nest.

To determine the number of eggs layed by each species, abandoned nests were collected, after the larvae started their solitary stage. The nests, which are built around the eggs, were cleaned of their protective
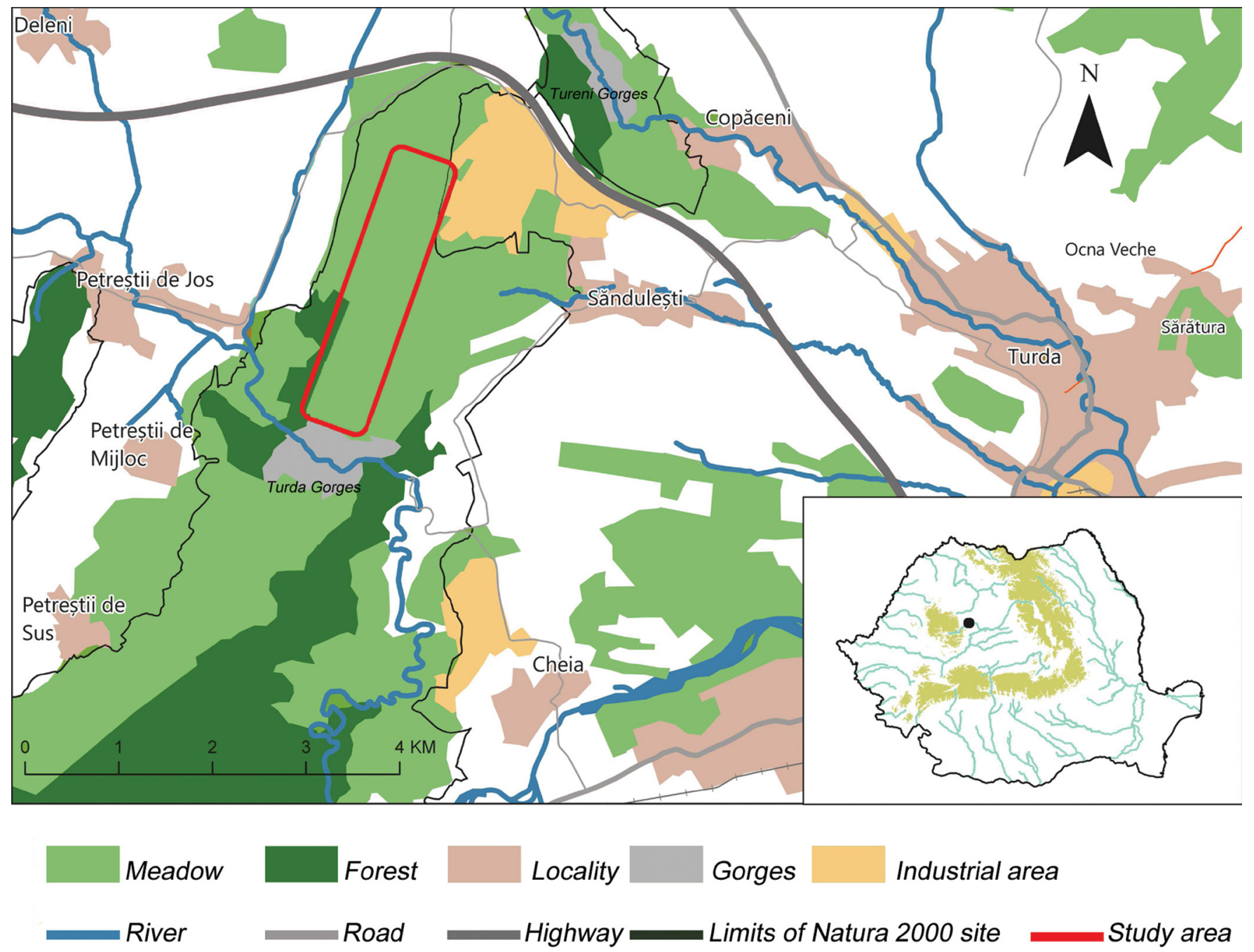

Fig. 1. Map of the studied area and its surroundings. 


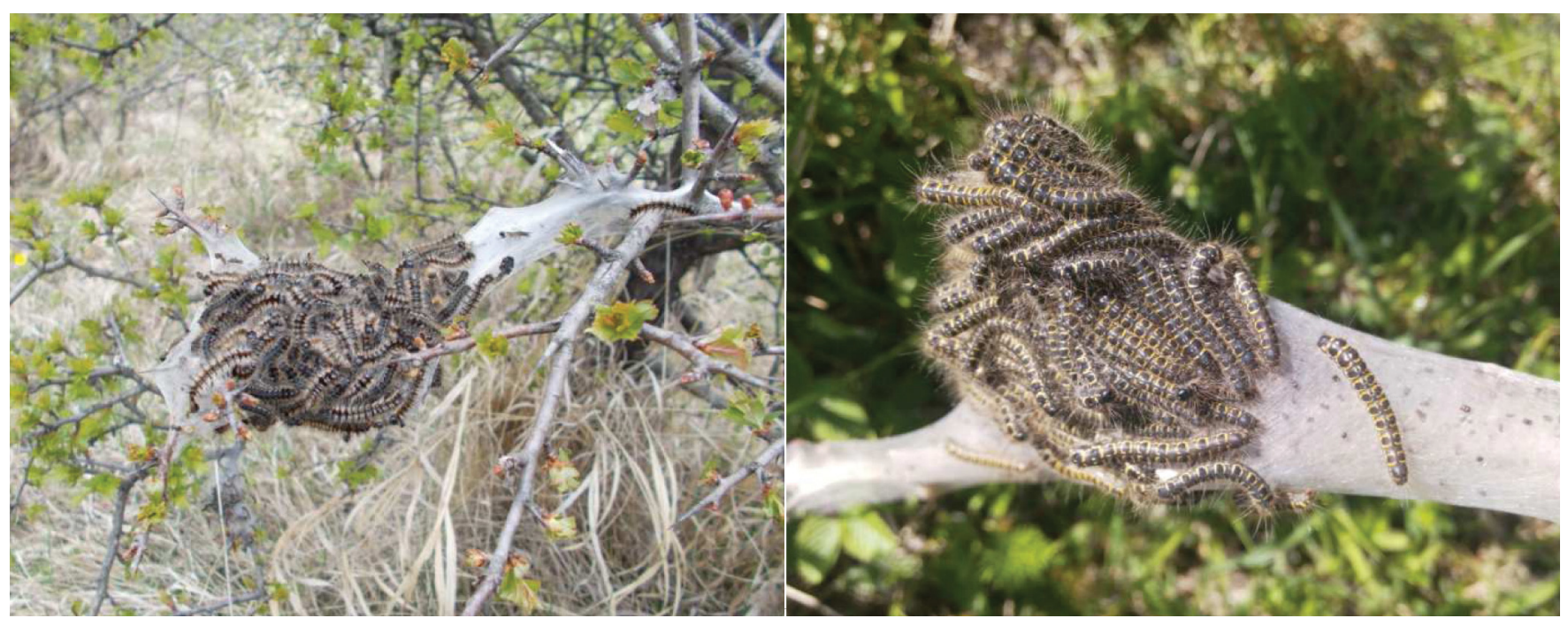

Fig. 2. Nest and caterpillars of E. catax (left) and nest and caterpillars of E. lanestris (right)

hairs coming from the abdominal area of the females and counted using an Olympus stereo microscope. In order to avoid double counting, the eggs were stained with a permanent marker. The total number of eggs, total number of hatched and unhatched eggs were conclusive for the fertility percent.

\section{Statistical analysis}

Statistical analysis were performed using the EpiInfo $7^{\mathrm{TM}}$ software (CDC, USA) and the EpiTools website (http://epitools.ausvet.com.au). For each type of plant, the frequency and its $95 \%$ confidence interval $(95 \% \mathrm{CI})$ were calculated and differences were assessed by chi square testing. On the basis of chi square values, in respect to the degrees of freedom (d.f.), the differences were considered significant for $p<0.05$. For determining oviposition preferences, 20 $\mathrm{cm}$ height intervals were designated from soil level, up to the interval of the highest recorded clutch. The designated intervals were from0-20 cm, up to 161 $180 \mathrm{~cm}$. For each interval, the frequency and 95\% confidence intervals $(95 \% \mathrm{CI})$ were calculated and chi square test was used for comparison. The mean values for the two species were compared using MannWhitney/Wilcoxon Two-Sample Test (Kruskal-Wallis test for two groups). The correlation between the total height of the host plant and clutch height was inferred by Spearman's rank correlation test. The mean number of deposited and unhatched eggs was established for each species and the differences were assessed by means of T-test. All metric data are reported as mean values \pm standard deviation.

\section{Results}

During our study, 48 nests of $E$. catax between 481$739 \mathrm{~m}$ altitude and 111 nests of $E$. lanestris between 550-752 m altitude were inventoried and measured.
The mean altitude of the recorded $E$. catax nests was $686.64 \pm 76.53 \mathrm{~m}$ and that of $E$ lanestris was 710.67 $\pm 57.74 \mathrm{~m}$.

\section{The cardinal orientation of the slope for sampling locations}

In our study site, both species occupied shrubs located in the plateau region of the left slope of the Gorges, in full sunlight.

A higher frequency in E. catax distribution was attributed to the SE slope $37.5 \%$ (95\% CI 23.95 $52.65 \%$ ), with a lower frequency, of $27.08 \%(95 \%$ CI 15.28-41.85\%) on E and NW slopes (Fig. 3). The distribution of the nests according to cardinal points

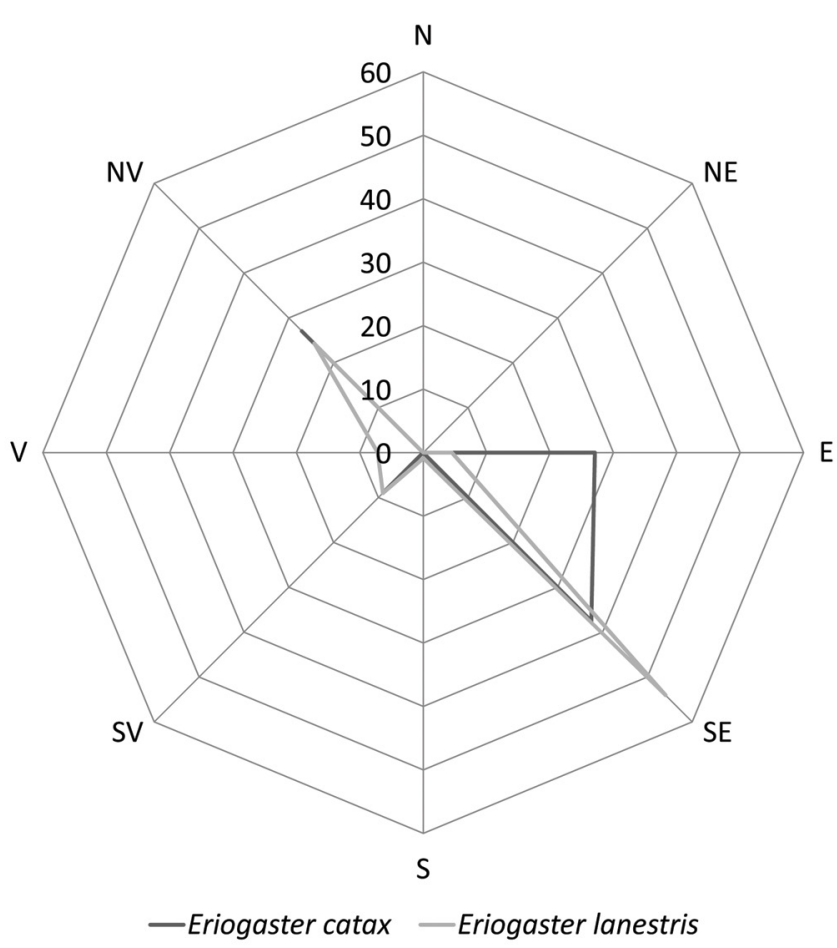

Fig. 3. Preference for the cardinal orientation. 
was significant $\left(\chi^{2}=11.33 ;\right.$ d.f. $\left.=5 ; \mathrm{p}=0.0101\right)$.

E. lanestris was more abundant on SE slopes, with a frequency of $54.05 \%$ (95\% CI $44.33-63.55 \%)$, with a low threshold on NW slopes, $24.32 \%$ (95\% CI16.68$33.38 \%$ ).

E. lanestris was more confined to the cardinal direction when compared to E. catax, but with no statistical significance $\left(\chi^{2}=3.04\right.$; d.f. $\left.=1 ; p=0.0811\right)$.

\section{The choice of host plant used as larval food source}

The larvae of $E$. catax were found with a higher frequency on $P$. spinosa, $62.5 \%$ (95\% CI 47.35 $76.05 \%$ ) and in reduced numbers on Crataegus spp. $37.5 \%$ (95\% CI $23.95-52.65 \%)$. The preference for $P$. spinosa was statistically significant $\left(\chi^{2}=5.04\right.$; d.f. $=1$; $\mathrm{p}=0.0242)$. The larvae of E. lanestris also displayed a higher frequency on $P$. spinosa, $86.49 \%$ (95\% CI -78.69-92.23) and a low presence on Crataegus spp. $13.51 \%$ (95\% CI 7.77-21.31\%), having a significant preference for $P$. spinosa $\left(\chi^{2}=115.31\right.$; d.f. $\left.=1 ; \mathrm{p}=0\right)$.

Both species showed significant affinities towards the same host plant, but more markedly E. lanestris $\left(\chi^{2}=10.3 ;\right.$ d.f. $\left.=1 ; p=0.0011\right)$.

\section{Oviposition choice in relation to the shape and structure of the shrub}

E. catax was more confined to grouped shrubs, with a frequency of $62.5 \%$ (95\% CI $47.35-76.05 \%$ ), as opposed to solitary ones, with $37.5 \%$ frequency (95\% CI 23.95-52.65\%), with a statistical significance $\left(\chi^{2}=5.04 ;\right.$ d.f. $\left.=1 ; \mathrm{p}=0.0242\right)$.

E. lanestris displayed a higher frequency $90.09 \%$ (95\% CI 82.96-94.95\%) of oviposition on grouped shrubs, while solitary shrubs presented a low percentage, of $9.91 \%$ (95\% CI 5.05-17.04\%). The differences were statistically significant $\left(\chi^{2}=139.53\right.$; d.f. $=1 ; \mathrm{p}=0$ ).

E. lanestris exhibited significantly increased confinement to grouped shrubs as opposed to E. catax $\left(\chi^{2}=15.3 ;\right.$ d.f. $\left.=1 ; p<0,0001\right)$.

\section{Host plant height}

The mean height of the host plants reflecting the affinities of $E$. catax was of $90.6 \pm 59.99 \mathrm{~cm}$, while for the other species, E. lanestris, it was of 52.88 $\pm 31.57 \mathrm{~cm}$. According to data from $P$. spinosa shrubs, the mean height preference of E. catax was 74.93 $\pm 50.23 \mathrm{~cm}$, while that of E. lanestris was of 50.66 $\pm 24.87 \mathrm{~cm}$. For the second host plant, Crataegus spp., the mean height for E. catax clutches was of $116.72 \pm 67.01 \mathrm{~cm}$, while $E$. lanestris displayed a lower threshold, of $67.06 \pm 58.18 \mathrm{~cm}$. The global height difference between the host plants in relation to species oviposition preferences was significant $(\mathrm{H}=13.74 ; \mathrm{df}=1 ; \mathrm{p}=0.0002)$. Significant differences in height preferences of the two species were recorded for both $P$. spinosa $(\mathrm{H}=5.62 ; \mathrm{df}=1 ; \mathrm{p}=0.0177)$ and Crataegus spp. $(\mathrm{H}=4.274 ; \mathrm{df}=1 ; \mathrm{p}=0.0318)$.

The analysis of shrub height distribution on $50 \mathrm{~cm}$ intervals revealed a different oviposition pattern of E. catax, with first choice for the $0-50 \mathrm{~cm}$ interval, with a frequency of $41.67 \%$ (95\% CI 27.61-56.79\%), followed by the $51-100 \mathrm{~cm}$ interval, with a frequency of $27.08 \%$ (95\% CI $15.28-41.85 \%$ ), with significant differences among intervals $\left(\chi^{2}=28.02\right.$; d.f. $\left.=4 ; p=0\right)$.

The analysis of shrub height distribution on $50 \mathrm{~cm}$ intervals exhibited the same oviposition pattern for $E$. lanestris, with first choice for the $0-50 \mathrm{~cm}$ interval, $63.06 \%$ frequency (95\% CI 53.38-72.03\%), followed by the $51-100 \mathrm{~cm}$ interval, $32.43 \%$ frequency $(95 \% \mathrm{CI}$ 23,85-41,97\%), with significant differences between

Table 1 . The frequency and 95\% CI of height intervals of host plants. Maximum values are highlighted in grey.

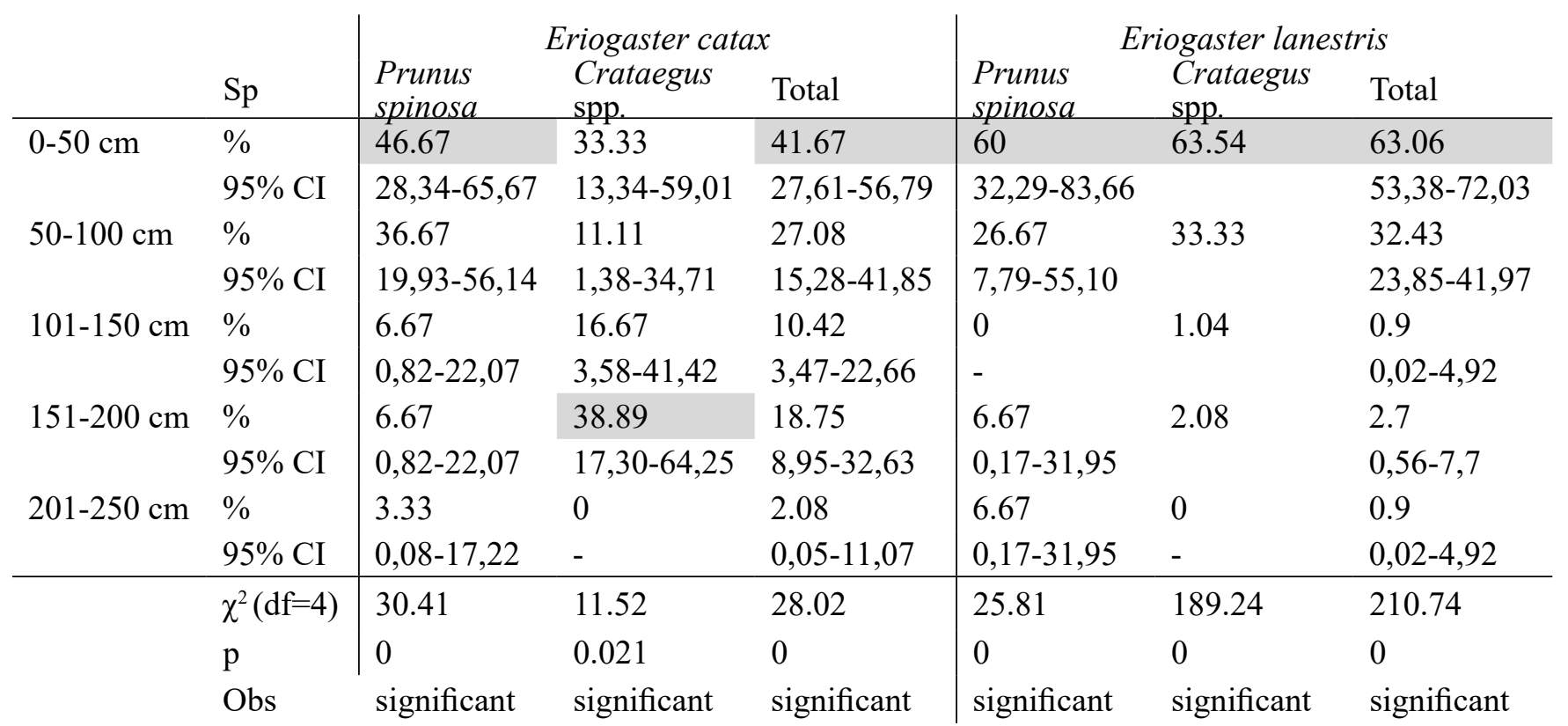


intervals $\left(\chi^{2}=210.74 ;\right.$ d.f. $\left.=4 ; p=0\right)($ Table 1$)$.

As revealed previously, E.lanestris is significantly more confined to the $0-50 \mathrm{~cm}$ height interval when compared to $E$. $\operatorname{catax}\left(\chi^{2}=5.40 ;\right.$ d.f. $\left.=1 ; \mathrm{p}=0.0149\right)$.

\section{Oviposition height}

The mean height of oviposition on the host plants was $57.89 \pm 25.34 \mathrm{~cm}$ for E. catax and $45.12 \pm 23.87$ $\mathrm{cm}$ for E. lanestris. The global difference between the two species was significant $(\mathrm{H}=13.6$; d.f. $=1$; $\mathrm{p}=0.0002)$. On $P$. spinosa, the mean oviposition height was $53.23 \pm 22.84 \mathrm{~cm}$ for $E$. catax and $43.84 \pm 20.15$ $\mathrm{cm}$ for $E$. lanestris. The difference was statistically significant $(\mathrm{H}=5.27$; d.f. $=1 ; \mathrm{p}=0.0217)$. On Crataegus spp., the mean oviposition height was $65.66 \pm 27.97 \mathrm{~cm}$ for E. catax and $53.33 \pm 40.5 \mathrm{~cm}$ for E. lanestris. The difference was statistically significant $(\mathrm{H}=4.26$; d.f. $=1 ; \mathrm{p}=0.0390$ ).

Analyzing the distribution of the nests on $20 \mathrm{~cm}$ height intervals, E. catax displayed a preference for the $41-60 \mathrm{~cm}$ interval, with a frequency of $37.5 \%$ (95\% CI $23.95-52.65 \%$ ), closely followed by the $21-40 \mathrm{~cm}$ interval, with a frequency of $27.08 \%$ (95\% CI 15.28 $41.85 \%$ ). The differences between height intervals were statistically significant $\left(\chi^{2}=75.51 ;\right.$ d.f. $\left.=8 ; p=0\right)$.

$E$. lanestris showed a different pattern of oviposition, with first choice for the 21-40 cm interval, with a frequency of $47.75 \%$ (95\% CI 38.18 $57.44 \%$ ) and second for the 41-60 cm interval, with a frequency of $34.23 \%$ ( $95 \%$ CI $25.49-43.84 \%$ ). The differences between height intervals were statistically significant $\left(\chi^{2}=92.97 ;\right.$ d.f. $\left.=8 ; p=0\right)($ Table 2$)$.

By analyzing the nests distribution on $20 \mathrm{~cm}$ height intervals and taking into account the host plant, $E$. catax displayed slightly different patterns. On $P$. spinosa the most frequent interval was $21-40 \mathrm{~cm}$, with $36.67 \%$ frequency (95\% CI 19.93-56.14\%), followed by $41-60 \mathrm{~cm}$ with $33.33 \%$ frequency $(95 \%$ CI 17,29 $52,81)$ and the differences among intervals were significant $\left(\chi^{2}=52.65\right.$; d.f. $\left.=8 ; \mathrm{p}=0\right)$. On Crataegus spp. most frequent interval was $41-60 \mathrm{~cm}$, with $44.44 \%$ frequency ( $95 \%$ CI $21.53-69.24 \%$ ), followed by 61 $80 \mathrm{~cm}$ with $27.78 \%$ frequency (95\% CI 9.69-53.48\%) and the differences among intervals were significant $\left(\chi^{2}=33.75 ;\right.$ d.f. $\left.=8 ; p=0\right)$.

By analyzing the clutch distribution on $20 \mathrm{~cm}$ height intervals and taking into account the host plant, E. lanestris displayed similar results. On $P$. spinosa the most frequent interval was $21-40 \mathrm{~cm}$ with $46.88 \%$ frequency (95\% CI 36.61-57.34\%), followed by $41-60 \mathrm{~cm}$ with $36.46 \%$ frequency $(95 \%$ CI 26.87-46.21\%) and significant differences among intervals $\left(\chi^{2}=71.96\right.$; d.f. $\left.=8 ; \mathrm{p}=0\right)$. On Crataegus spp. the most frequent interval was $21-40 \mathrm{~cm}$ with $53.33 \%$ frequency (95\% CI 26.59-78.73\%), followed by 41 -

Table 2. The frequency and 95\% CI of oviposition intervals. Maximum values are highlighted in grey.

\begin{tabular}{|c|c|c|c|c|c|c|c|}
\hline & & & riogaster catc & & & iogaster lanes & \\
\hline & $\mathrm{Sp}$ & $\begin{array}{l}\text { Prunus } \\
\text { spinosa }\end{array}$ & $\begin{array}{l}\text { Crataegus } \\
\text { spp. }\end{array}$ & Total & $\begin{array}{l}\text { Prunus } \\
\text { spinosa }\end{array}$ & $\begin{array}{l}\text { Crataegus } \\
\text { spp. }\end{array}$ & Total \\
\hline $0-20 \mathrm{~cm}$ & $\%$ & 0 & 0 & 0 & 4.16 & 0 & 3.6 \\
\hline & $95 \% \mathrm{CI}$ & - & - & - & $1,15-10,33$ & - & $0,99-8,97$ \\
\hline $21-40 \mathrm{~cm}$ & $\%$ & 36.67 & 11.11 & 27.08 & 46.88 & 53.33 & 47.75 \\
\hline & $95 \% \mathrm{CI}$ & $19,93-56,14$ & $1,38-34,71$ & $15,28-41,85$ & $36,61-57,34$ & $26,59-78,73$ & $38,18-57,44$ \\
\hline $41-60 \mathrm{~cm}$ & $\%$ & 33.33 & 44.44 & 37.5 & 36.46 & 20 & 34.23 \\
\hline & $95 \% \mathrm{CI}$ & $17,29-52,81$ & $21,53-69,24$ & $23,95-52,65$ & $26,87-46,21$ & $4,33-48,09$ & $25,49-43,84$ \\
\hline $61-80 \mathrm{~cm}$ & $\%$ & 16.67 & 27.78 & 20.83 & 8.33 & 13.33 & 9.01 \\
\hline & $95 \%$ CI & $5,64-34,72$ & $9,69-53,48$ & $10,47-34,99$ & $3,67-15,76$ & $1,66-40,46$ & $4,41-15,94$ \\
\hline $81-100 \mathrm{~cm}$ & $\%$ & 10 & 5.56 & 8.33 & 2.08 & 6.67 & 2.7 \\
\hline & $95 \% \mathrm{CI}$ & $2,11-26,53$ & $0,14-27,29$ & $2,32-19,98$ & $0,25-7,32$ & $0,17-31,95$ & $0,56-7,7$ \\
\hline $101-120 \mathrm{~cm}$ & $\%$ & 0 & 5.56 & 2.08 & 0 & 0 & 0 \\
\hline & $95 \% \mathrm{CI}$ & - & $0,14-27,29$ & $0,05-11,07$ & - & - & - \\
\hline $121-140 \mathrm{~cm}$ & $\%$ & 3.33 & 5.56 & 4.17 & 2.08 & 0 & 1.8 \\
\hline & $95 \% \mathrm{CI}$ & $0,08-17,22$ & $0,14-27,29$ & $0,51-14,25$ & $0,25-7,32$ & - & $0,22-6,36$ \\
\hline $141-160 \mathrm{~cm}$ & $\%$ & 0 & 0 & 0 & 0 & 0 & 0 \\
\hline & $95 \% \mathrm{CI}$ & - & - & - & - & - & - \\
\hline $161-180 \mathrm{~cm}$ & $\%$ & 0 & 0 & 0 & 0 & 6.67 & 0.9 \\
\hline & $95 \% \mathrm{CI}$ & - & - & - & - & $0,17-31,95$ & $0,02-4,92$ \\
\hline & $\chi^{2}(\mathrm{df}=8)$ & 52.65 & 33.75 & 75.51 & 71.96 & 25.51 & 92.97 \\
\hline & $\begin{array}{l}\mathrm{p} \\
\text { Obs }\end{array}$ & $\begin{array}{l}0 \\
\text { significant }\end{array}$ & $\begin{array}{l}0 \\
\text { significant }\end{array}$ & $\begin{array}{l}0 \\
\text { significant }\end{array}$ & $\begin{array}{l}0 \\
\text { significant }\end{array}$ & $\begin{array}{l}0.0003 \\
\text { significant }\end{array}$ & $\begin{array}{l}0 \\
\text { significant }\end{array}$ \\
\hline
\end{tabular}


$60 \mathrm{~cm}$ with $20 \%$ frequency (95\% CI $4.33-48.09 \%$ ) and significant differences among intervals $\left(\chi^{2}=25.51\right.$; d.f. $=8 ; \mathrm{p}=0.0003$ ).

In relation to $P$. spinosa, both species exhibited a specific preference for the 21-40 cm height interval, without significant differences among them $\left(\chi^{2}=0.2208\right.$; d.f. $\left.=1 ; p=0.4016\right)$.

For both species, a very strong and statistically significant correlation between host plant height and oviposition height was noted ( $\mathrm{R}=0.80274 ; \mathrm{p}=0$ for $E$. catax and $\mathrm{R}=0.86508 ; \mathrm{p}=0$ for E. lanestris $)$.

\section{Deposited eggs and fertility}

The mean number of deposited eggs was of 273.48 $\pm 50.19(\mathrm{~N}=54)$ for E. lanestris and $181.67 \pm 48.24$ $(\mathrm{N}=48)$ for $E$. catax, with statistically significant differences among the two species $(p=0.003)$. With regards to fertility, the number of unhatched eggs per nest ranged between 0 and 61 (mean $7.46 \pm 13.03$ )for E. lanestris andbetween 0 and 5 (mean $3.67 \pm 2.16$ ) for $E$. catax. However, the differences were not statistically significant $(\mathrm{p}=0.06)$.

\section{Discussion}

Regarding the altitude, these species are confined to lowland areas, but in Eastern Europe and Asia Minor, they were recorded also from over $1500 \mathrm{~m}$. In Spain, the species are confined to submontane areas, at altitudes ranging between 530 and $1500 \mathrm{~m}$ (DE Freina 1996; GARCíA-PÉREZ et al. 2009). In our case, the mean altitude for the recorded clutches of E. catax and E. lanestris are at the mean of the $500-1500 \mathrm{~m}$ interval.

The solar intensity may influence the oviposition sites for both species. E. catax is confined to thermo-hydrophilic habitats in Germany and Switzerland (BOLz 2001, CARRON 2009), while in France and Austria, it occurs xero-thermophilic areas (Hottinger 2005, Baillet 2013), on sunny calcareous slopes, forest edges or glades (DE FreINA 1996, Borges 2012). The habitat included in our study from Turda Gorges is characterised by xerothermophilic conditions on calcareous bedrock, a suitable condition for xero-thermophilic species like E. lanestris (EBERT 1994, RUF et al. 2003). E. catax lays its eggs on branches with southern, south-eastern or eastern exposure (MALKIEWICZ 2015). In our study site, both species were mostly confined to SE slopes (E. catax $37.5 \%$, and E. lanestris $54.05 \%$ ), with the nest built on the sunny side of the branch.

In Romania, the two species are mainly found in grassland-type agroecosystems, used both for animal grazing and hay production. The traditional management of these terrains has allowed the maintenance of mosaic landscape including hedges of P. spinosa, Crataegus spp., Rosa spp., Pyrus pyraster,
Amygdalus nana etc. This type of habitat with bushes belongs to type $40 \mathrm{~A} 0 *$ - Subcontinental peri-Pannonic scrub according to Annex I of Council Directive 92/43/EEC (Doniță et al. 2005). The primary larval food plants of the species are $P$. spinosa and Crataegus spp. Other host plants like C. laevigata, Pyrus spp., Quercus spp. or Berberis spp., were reported (RuF and Fiedler 2005, HötTINGER 2005, BORGES 2012, Baillet 2013, ChrZanowski et al. 2013, Bury 2015, Malkiewicz 2015). In the studied area, all the nests were encountered on P. spinosa and Crataegus spp. with the exception of a single $E$. catax nest observed on Berberis spp. Some authors (Malkiewicz 2015) report $P$. spinosa as the main food plant for E. catax and rarely Crataegus spp. as a secondary food plant. Our data further confirm this aspect. However, in Eastern Austria, the females lay on Crataegus spp. as a first option and only secondary on $P$. spinosa. This assumption relies on the identification of hundreds of nests and entomological inquiries (BoLz 1998, 2001, HötTINGER 2005). The study of CARron (2009) also showed a greater preference for Crataegus spp. (52\% of cases). The same preference was noted in Spain, where $E$. catax was encountered with a higher frequency on Crataegus spp. (63\%, N =35) (GARCÍAPÉREZ et al. 2009). In contrast, studies conducted in Germany (Weidemann and KoHLER 1996), as well as in Poland (Bury 2015, Malkiewicz 2015, KadEJ et al. 2018) also confirm more nests identified on P. spinosa in opposition to Crataegus spp. Our study suggests significant preferences of both species in relation to larval host plant, with $E$. lanestris displaying a greater preference than $E$. catax. Both species exhibited a greater affinity for P. spinosa (E. catax $62.5 \%, E$. lanestris $86.49 \%$ ). The preference for the host plant is most probably reflected by the parameter of the area that may vary from one population to another.

Studies emphasizing oviposition preferences of E. catax females showed edges of dense and isolated shrubs as preferred sites (MALKIEWICZ 2015). Our results display a greater preference for grouped shrubs than isolated ones (E. catax $62.5 \%$ grouped, $37.5 \%$ isolated and E. lanestris $90.09 \%$ grouped). Considering the height, and implicitly the reduced height of the shrubs, grouped shrubs may be favorable for larval access to food during the whole developmental period, without the necessity of migration to other shrubs.

Females of E. catax and E. lanestris always lay their full egg complement into one egg batch (RUF et al. 2003), thus an exact determination of the number of eggs laid by the two species of moths was possible. According to RUF et al. (2003), E. lanestris lays $323 \pm 71$ eggs/cluster $(\mathrm{N}=20)$, while $E$. catax has a mean number of $183 \pm 40$ eggs/cluster $(\mathrm{N}=39)$. The number of eggs/cluster determined in the present study was similar. However, the percentage of hatched eggs herein reported (97.28\% for E. lanestris and $97.99 \%$ 
for $E$. catax) was greater than the one determined by RuF et al., (2003) (86\% for E. lanestris, 79\% for $E$. catax). Our study was performed exclusively in the field, showing the existence of vigorous populations. The difference in the number of laid eggs between the two species can be explained by the larger size of $E$. catax eggs compared to those of E. lanestris, as noted during personal observations, but also by other authors (RUF et al. 2003).

The previously reported clutches of $E$. catax were placed at a height of minimum $100 \mathrm{~cm}$ (BORGEs 2012), almost twice the size of the mean $(57.89 \pm 25.34 \mathrm{~cm})$ identified in the colonies from our study. Also, a study on clutch height conducted in Poland displays a height interval of 50-200 cm (MALKIEwICZ 2015). However, the first study that statistically demonstrates the existence of a preferred oviposition interval was recently conducted (KADEJ et al. 2018) indicating an interval ranging between 75 and $127 \mathrm{~cm}$, with a median value of $91 \mathrm{~cm}$. The mean height of the E. lanestris clutches identified in our study, $(45.12 \pm 23.87 \mathrm{~cm})$, is close to that of $E$. catax $(57.89 \pm 25.34 \mathrm{~cm})$. For both species, the majority of clutches were recorded at a height ranging from 21 to $60 \mathrm{~cm}$. However, E. catax mainly oviposits in the $41-60 \mathrm{~cm}$ interval, while $E$. lanestris prefers the $21-40 \mathrm{~cm}$ interval.

In the absence of other studies referring to oviposition height of E. lanestris no comparison degree between more populations is currently available.

A differentiated analysis of the oviposition height of E. catax in relation to host plant in the canton of Geneva reported a mean oviposition height of 120 $\mathrm{cm}$ for clutches laid on Crataegus spp. (CARRON 2009). In contrast, our study showed a lower mean height, of $65.66 \pm 27.97 \mathrm{~cm}$ on Crataegus spp. On P. spinosa the oviposition height ranged between 30 and $170 \mathrm{~cm}$, with a mean height of $90 \mathrm{~cm}$, which is also higher compared toour results $(53.23 \pm 22.84)$. Data from literature (CARRON 2009) and our study indicate higher oviposition sites on Crataegus spp. in opposition to P. spinosa for both E. catax and $E$. lanestris. The mean oviposition height according to host plant were slightly higher in the case of E. catax, but they are nevertheless similar.

The lower oviposition height from our study, as compared to previous data, may be explained by reduced size of the host plants. The mean oviposition height may vary also among different populations. This aspect needs further studies on other populations and the correlation of the results with the physicgeographical and climatic variables. Our results indicate preference for the low height shrubs for both species. Both species lay eggs on the shrubs with a height ranging between $0-50 \mathrm{~cm}$ (E. catax $41.67 \%$ and E. lanestris $63.96 \%$ ), but E. lanestris showed a significantly greater preference in comparison to E. catax for this height interval. KADEJ et al.
(2018) obtained a moderate correlation between the oviposition height and the total plant height for $E$. catax. The strong correlation revealed by the present study may be linked to the general low height of the shrubs, as a consequence of sheep and goat grazing in the area. In Romania, sheep rearing is encouraged and sustained by the government, grazing being allowed including in Natura 2000 sites. The regulations for obtaining agricultural subsidy state a minimum number of sheep that farmers should own but not a maximum one, which may result in overgrazing on pastures. Most pastures are concessional for a limited period of time, consequently sheep farmers have no interest in sustainable exploitation of the land. Furthermore, farmers have the obligation to remove shrubs from pastures. In some cases, this is performed by mechanical removal, but in most situations, fire is being used in spring or autumn, with no regard for the potential occurrence of endangered species.

Knowledge on the oviposition in the entire distribution area is essential for establishing adequate management measures for the conservation of meadows with shrubs, which represent a particular type of habitat including high biodiversity of insects (BAUR et al. 2006, Loos et al. 2014), an important food source for pollinators such as solitary bees (GRESTY et al. 2018), a high diversity of birds (CARLOS and GiBson 2010) and numerous small or medium-sized mammals (Biala et al. 2005).

Another important aspect for the conservation of E. catax is the distance between terrains harboring potential habitats and the existence of ecological corridors to ensure genetic exchange between populations, considering the low dispersal capacity of the females (CARRON 2009). Therefore, more data concerning the dispersion capacity of this species is required (KADEJ et al. 2018).

\section{Conclusions}

The present study provides important data which can be used to design an appropriate management plan for the species conservation of E. catax. Furthermore, it reveals a series of similarities between E. catax and E. lanestris concerning habitat preferences and ecological needs when choosing the oviposition site. According to these requirements, more attention should be given to E. lanestris, as its occurrence may be an indicator for the potential concurrent presence of E. catax.

\section{Acknowledgements}

This study was partly funded by the Mohamed bin Zayed Species Conservation Fund through the project number 150511930 Awareness for conservation of $E$. catax in Cluj county, Romania, a IUCN Data Deficient Species. We are grateful to Bogdan Constantin for his help with the creation of map. 


\section{References}

Agenția de Plăți și Intervenție pentru agricultură (2019) [WWW document]. URL http://www.apia.org.ro/ [accesed on 5 January 2019] (in Romanian).

Alcántara de la Fuente M. (2009) Reseña: Catálogo de Especies Amenazadas en Aragón: Fauna. [Review: Catalogue of endangered species in Aragon: Fauna]. Boletín Sociedad Entomológica Aragonesa 44: 643648 (in Spanish).

Anthes N., Fartmann T. and Hermann G. (2008) The Duke of Burgundy butterfly and its dukedom: larval niche variation in Hamearis lucina across Central Europe. Journal of Insect Conservation 12: 3-14.

BAILlET Y. (2013) Inventaire et suivi de Eriogaster catax (Laineuse du Prunellier) sur l'ENS des Communaux de Trept. Rapport d'étude de Flavia, A.D.E Trept, pp. 41 (in French).

Baur B., Cremene C., Groza G., Rákosy L., Schileyko A.A., Baur A., Stoll P. and ERhardt A. (2006) Effects of abandonment of subalpine hay meadows on plant and invertebrate diversity in Transylvania, Romania. Biological Conservation 132: 261 - 273.

BeAufoy G. (1998) The EU Habitats Directive in Spain: can it contribute effectively to the conservation of extensive agro-ecosystems? Journal of Applied Ecology 35: 974-978.

Biala K., Peeters A., Muys B., Hermy M., Brouckaert V., García V., VAN DeR VeKen B. and ValckX J. (2005) Biodiversity indicators as a tool to assess sustainability levels of agro-ecosystems, with a special consideration of grassland areas. Options Méditerranéennes, Series A, 67: 439-443.

Bignal E.M. and McCRACKen D.I. (1996) Low-intensity farming systems in the conservation of the countryside. Journal of Applied Ecology 33: 413-424.

Bolz R. (1998) Zur Biologie und Ökologie des Heckenwollafters Eriogaster catax (LINNAEUS, 1758) in Bayern (Lepidoptera: Lasiocampidae). [Notes on biology and ecology of the lasiocampid moth Eriogaster catax LinNAEUS, 1758 in Bavaria (Lepidoptera: Lasiocampidae)]. Nachrichtendes Entomologische. Vereins. Apollo 18: 331-340 (in German).

Bolz R. (2001) Hecken-Wollafter (Eriogaster catax) - Berichtspflichten in Natura-2000-Gebieten. Empfehlungen zur Erfassung der Arten des Anhangs II und Charakterisierung der Lebensraumtypen des Anhangs I der FFH-Richtlinie (ed. by T. FARTMAnN, H. Gunnemann, P. Salm and E. SchröDER). Angewandte Landschaftsökologie 24: 358-362.

Borges A. (2012) En quête d'insectes - La Laineuse du prunellier - 2 localisation des chenilles (dans les nids communautaires): c'est maintenant! [In search of insects - Eastern eggar -2 locations of caterpillars (in community nests): it's now!] Insectes 37: 164 (in French).

BuRY J. (2015) Nowe dane o występowaniu Eriogaster catax (LinNAEUS, 1758) (Lepidoptera: Lasiocampidae) w południowo-wschodniej Polsce. [New data on occurrence of Eriogaster catax (LinNAEUs, 1758) (Lepidoptera: Lasiocampidae) in south-eastern part of Poland] Acta entomologica silesiana 23: 1-10 (in Polish)

Carlos E.H. and Gibson M. (2010) The habitat value of Gorse Ulex europaeus L. and Hawthorn Crataegus monogyna Jacq. for birds in Quarry Hills Bushland Park, Victoria. Victorian Naturalist 127: 115-124.

CARon G. (2009) La laineuse du prunellier Eriogaster catax (LinNAEUS, 1758) (Lepidoptera, Lasiocampidae) victime des changements climatiques? Ecologie de l'espèce et hypothèses sur son déclindans la region genevoise. [Is Eriogaster catax (Linnaeus, 1758) (Lepidoptera, Lasiocampidae) a victim of climatic change? Ecology of the species and hypotheses concerning its decline in the Geneva region]. Entomo Helvetica 2: 49-60 (in French).

ČELIK T. (2013) Oviposition preferences of a threatened butterfy Leptidea morsei (Lepidoptera: Pieridae) at the western border of its range. Journal of Insect Conservation 17: 865-876.

Čelik T., Bräu M., Bonelli S., Cerrato C., Vrě̌ B., Balletto E., Stettmer C. and Dolek M. (2015) Winter-green host-plants, litter quantity and vegetation structure are key determinants of habitat quality for Coenonympha oedippus in Europe. Journal of Insect Conservation 19: 359-375.

Chrzanowski A., Kuźmiński R., ŁabęDzKi A., Mazur A. and RutKowsKi P. (2013) Occurrence of Eriogaster catax (LINNAEUS, 1758) (Lasiocampidae, Lepidoptera) and the proposed protective actions on the Polish territory. Nauka Przyroda Technologie 7, 2, \#24.

Costa J.T. (1997) Caterpillars as social insects. American Scientist 85: 150-159.

Doniţă N., PoPescu A., PAUCĂ-COMĂNeSCU M., MiHĂILESCU S. and BIRIŞ I.A. (2005). Habitatele din România. [The habitats of Romania] Edit. Tehnică Silvică, Bucureşti, pp. 500 (in Romanian).

DoleK M, Freese-Hager A., Geyer A. and Liegl A. (2008) Die Habitatbindung von Maivogel und Heckenwollafter: Ein Vergleich von zwei Lichtwaldarten, In: Umwelt Spezial. Ökologische Bedeutung und Schutz von Mittelwäldern in Bayern, Bayerisches Landesamt für Umwelt, pp. 38-55 (in German).

Drews, M., WaChlin, V. (2003) Eriogaster catax (Linnaeus, 1758). Das europäische Schutzgebietssystem Natura 2000. Ökologie und Verbreitung von Arten der FFH-Richtlinie in Deutschland. Band 1: Pflanzen und Wirbellose (ed. by B. Petersen, G. Ellwanger, G. Biewald, U. Hauke, G. Ludwig, P. Pretscher, E. Schröder and A. Symank) Schriftenreiche für. Landschaftspflege und Naturschutz 69/1: 459-464 (in German).

Dubatolov V.V. and Zolotuhin V.V. (1992) A list of the Lasiocampidae from the territory of the former USSR (Insecta, Lepidoptera), Atalanta 23 (3/4): 531-548.

EBERT G. (1994) Die Schmetterlinge Baden-Württembergs. Band 4, Nachtfalter II. Ulmer Verlag, Stuttgart, pp. 535 (in German).

Ebert G., Hofmann A., Meineke J.-U., Steiner A. and Trusch R. (2005): Rote Liste der Schmetterlinge (Macrolepidoptera) Baden-Württembergs (3. Fassung). - In: Ebert, G. (Hrsg.): Die Schmetterlinge BadenWürttembergs, Band 10: 110-136; Verlag Eugen Ulmer/ Stuttgart.

FARKAČ J., KRÁL D., ŠKORPÍK J. (2005) Červený seznam ohrožených druhů České republiky. Bezobratlí. [Red list of threatened species in the Czech Republic. Invertebrates]. Agentur aochrany prrírody a krajiny ČR, Praha. pp. 760 (in Czech).

FitzGERALD T.D. and CosTA J.T. (1999) Collective behavior in social caterpillars. Information processing in social insects (ed. by C. Detrain, J. L. Deneubourg and J. M. Pasteels), pp. 379 - 400. Birkhäuser Verlag, Basel.

De Freina J.J. (1996) Eriogaster catax (Linnaeus, 1758). Background information on invertebrates of the Habitat Directive and the Bern Convention. Part I: Crustaceae, Coleoptera and Lepidoptera (ed. by P. J. HelsDingen, L. VAN Willemse and M.C.D. Speight) Nature and Environment 79: 117-120.

De Freina J.J. and Witt T.J. (1987) Die Bombyces und Sphinges der Westpaläarktis (Insecta, Lepidoptera). 
Edition Forschung und Wissenschaft, München. (in German).

Dover J. and Sparks T. (2000) A review of the ecology of butterfies in British hedgerows. Journal of Environmental Management 60: 51-63.

FORMAN R.T.T. and BAUDRY J. (1984) Hedgerows and hedgerow networks in landscape ecology. Environmental Management 8: 495-510.

Furst M.A. and NASH D.R. (2009) Host ant independent oviposition in the parasitic butterfly Maculinea alcon. Biological Letters 6: 174-176.

García-PÉrez B., PAJarón J.L., Quintanilla A.M. and Munguira M.L. (2009) Datos sobre la biología de Eriogaster catax (Lepidoptera: Lasiocampidae) y nuevas citas de Cantabria, España. [Eriogaster catax (Lepidoptera: Lasiocampidae): natural history data and new records from Cantabria, Spain]. Boletín Sociedad Entomológica Aragonesa 44: 157-160 (in Spanish).

Gresty C.E.A., Clare E., Devey D.S., Cowan R.S., Csiba L., Malakasi P., Lewis O.T. and Willis K.J. (2018). Flower preferences and pollen transport networks for cavity-nesting solitary bees: Implications for the design of agri-environment schemes. Ecology and Evolution 8: 7574-7587.

Halada L., Evans D., Romão C. and Petersen J.-E. (2011) Which habitats of European importance depend on agricultural practices? Biodiversity and Conservation 20: 2365-2378.

HötTinger H. (2005) Der Hecken-Wollafter (Eriogaster catax L.) in Wien (Lepidoptera: Lasiocampidae). Endbericht einer Studie im Auftrag der Wiener Magistratsabteilung MA 22 (Umweltschutz), accessed 11.09.2014. (in German).

Joos B., Casey T.M., Fitzgerald T.D. and Buttemer W.A. (1988) Roles of the tent in behavioral thermoregulation of eastern tent caterpillars. Ecology 69: 2004-2011.

KADEJ M., ZAJĄC K. and TARNAWSKI D. (2018). Oviposition site selection of a threatened moth Eriogaster catax (Lepidoptera: Lasiocampidae) in agricultural landscape - implications for its conservation. Journal of Insect Conservation 22: 29-39.

KARShOLT O. and RAzOwSKI J.(1996). The Lepidoptera of Europe. A Distributional Checklist. Apollo Books. Stenstrup. Denmark. pp.380.

Loos J., Dorresteijn I., Hanspach J., Fust P., Rákosy L. and FisCHER J. (2014) Low-Intensity Agricultural Landscapes in Transylvania Support High Butterfly Diversity: Implications for Conservation. PLoS ONE, 9(7): e103256.

MALKIEWICZ A. (2015) Barczatka kataks w Krainie Łęgów Odrzańskich - występowanie, zagrożenia, zalecenia ochronne. Kronika Łęgów Odrzańskichnr Numer 1. Rzadkie i chronione zwierzęta Krainy Łęgów Odrzańskich - zagrożenia i perspektywy rozwoju: Zimowanie ptaków $w$ Krainie Łęgów Odrzańskich Prochowice (ed. by M. PIETKIEWICZ and $\mathrm{H}$. SzTwiertnia). ISBN: 978-83-942200-0-6 (in Polish).

Manci C.O., Sitar C., Corduneanu C. and Bălan C. (2015) First contribution to the study of lepidopteran fauna (Insecta: Lepidoptera) from Stânca, Iași, Moldova region (Romania). Mnemosyne 6: 31-47.

Matson P.A., Parton W.J, Power A.G. and Swift M.J. (1997) Agricultural intensification and ecosystem properties. Science 277: 504-509.

MercKx T. and Berwaerts K. (2010) What type of hedgerows do Brown hairstreak (Thecla betulae L.) butterfies prefer? Implications for European agricultural landscape conservation. Insect Conservation and Diversity 3(3): 194-204

Muntean I., Sitar C., Craioveanu C. and Rákosy L.
(2015) The effect of traditional land use of diurnal lepidoptera from Nature 2000 site "Dealurile Clujului Est”". Studia Universitatis Babeş-Bolyai Biologia, LX, 1: 95-105.

Nagy H.B. and LÁszlo Z. (2014) Specii de interes comunitar de coleoptere si lepidoptere in Aria Naturală Protejată Râul Tur, Satu Mare. [Beetle and butterfly species of community interest in the River Tur protected area]. Satu Mare Studii și Comunicări Seria Științele Naturii 14: 13-35. (in Romanian).

NyARADY I.E. (1939) Enumerarea plantelor vasculare din Cheia Turzii. [The enumeration of vascular plants from the Turda Gorge]. Comisia Monumentelor Naturii, București (in Romanian).

Plieninger T., Höchtl F. and Spek T. (2006) Traditional land-use and nature conservation in European rural landscapes. Environmental Science and Policy 9: 317321.

Pro Natura, Schweizerischer Bund Für Naturschutz (2000) Schmetterlinge und ihre Lebensräume: Arten, Gefährdung, Schutz; Schweiz und angrenzende Gebiete. [Butterflies and their habitats: species, endangerment, protection; Switzerland and adjacent areas]. Band 3. Fotorotar AG, Egg (in German).

RÁKosy L. (1995) Die Noctuiden (Lepidoptera. Noctuidae) Siebenbürgens. Nachrichten des Entomologischen Vereins Apollo, Frankfurt/Main, N. F. Suppl. 13: 1-109.

RÁKosy L. and SzÉKelY L. (1996) Macrolepidopterele din sudul Dobrogei. [The Macrolepidoptera of southern Dobruja]. Entomologica Romanica 1: 17-62 (in Romanian).

RÁKOSY L. (2001) Diversität der Schmetterlinge (Lepidoptera) im Cheile Turzii Naturschutzgebiet (Siebenbürgen, Rumänien). [The Diversity of butterflies (Lepidoptera) in Turda Gorge Nature Reserve, Transylvania, Romania]. Entomologica romanica 6: 5-39 (in German).

Rákosy L., Goia M. and Kovács Z. (2003) Catalogul Lepidopterelor României /Verzeichnis der Schmetterlinge Rumänien. [The Catalogue of Romanian Lepidoptera] Societatea Lepidopterologică Română, Cluj-Napoca (in Romanian and German), 446 pp.

RÁkosy L. and VARGA Z. 2006. Der pannonische Raum und seine östlichen Interferenzen aus einer lepidopterologischen Perspektive. Beitr. Ent. 56 (2): 377-386.

RÁKosy L. (2008) 1074 Eriogaster catax: Natura 2000 in Romania. Species Fact Sheets. [WWW document]. URL http://www.crayfish.ro/anexe/SpeciesFactSheetsFeb08. pdf [accesed 14. May 2017].

ReFSNIDER J.M. and Janzen F.J. (2010) Putting eggs in one basket: ecological and evolutionary hypotheses for variation in oviposition site choice. Annual Review of Ecology Evolution and Systematics 41: 39-57.

RENWICK J.A.A. (1989) Chemical ecology of oviposition in phytophagous insects. Experientia 45: 223-228.

RuF C. and FIEDLER K. (2000) Thermal gains through collective metabolic heat production in social caterpillars of Eriogaster lanestris. Naturwissenschaften 87: 193-196.

Ruf C., Costa J. and Fiedler K. (2001) Trail-Based Communication in Social Caterpillars of Eriogaster lanestris (Lepidoptera: Lasiocampidae). Journal of Insect Behavior 14: 231-245.

RUF C. and FIEDLER K. (2002a) Plasticity in foraging patterns of colonies of the small eggar moth, Eriogaster lanestris (Lepidoptera: Lasiocampidae). Oecologia 131: 626-634.

RuF C. and Fiedler K. (2002b) Tent-based thermoregulation in social caterpillars of Eriogaster 
lanestris (Lepidoptera: Lasiocampidae): behavioral mechanisms and physical features of the tent. Journal of Thermal Biology 27: 493-501.

Ruf C., Freese A. and FiedLer K. (2003) Larval sociality in three species of central-place foraging lappet moths (Lepidoptera: Lasiocampidae): a comparative survey. Zoologischer Anzeiger - A Journal of Comparative Zoology 242: 209-222.

RUF C. and FIEDLER K. 1999 (2005) Colony survivorship of social caterpillars in the field: A case study of the small eggar moth (Lepidoptera: Lasiocampidae). Journal of Research on the Lepidoptera 38: 15-25.

SÁfián S. (2006) The occurrences of Eriogaster catax (LinNAEUS, 1758) and Eriogaster lanestris (LinNAEus, 1758) (Lepidoptera: Lasiocampidae) in the Körös Valley (South-Eastern Hungary) Folia Entomologica Hungarica 67: 137-143.

SzÉKeLY L. (2010) Moths of Romania, 1, - Fluturi de noapte din Romania 1 , - Hepialidae, Limacodidae, Cossidae, Thyrididae, Lasiocampidae, Endromidae, Saturniidae, Lemonidae, Sphngidae, Drepanidae, Thaumetopoeidae, Notodontidae, Pantheidae, Lymantriidae, Arctiidae, 10 col. pl., pp. 264, Disz-Tipo, Săcele (in Romanian).

TscharntKe T., KleIN A.M, Kruess A., STEFfanDewenter I. and Thies C. (2005) Landscape perspectives on agricultural intensification and biodiversity - ecosystem service management. Ecology Letters 8: 857-874.
VALCHÁŘová J. (2012) Vyhodnocení monitoringu evropsky významného druhu Eriogaster catax (Lepidoptera). [Evaluation of monitoring scheme for Eriogaster catax (Lepidoptera), species of European interest]. BSc. Thesis, pp. 49 Faculty of Science, University of South Bohemia (in Czech).

WEIDEMANN H.J. and KöHLER J. (1996) Nachtfalter: Spinner und Schwärmer. Naturbuch-Verlag, Augsburg, (in German).

WeHLing S. and DieKmann M. (2009) Importance of hedgerows as habitat corridors for forest plants in agricultural landscapes. Biological Conservation 142: 2522-2530.

Wuczyński A., Kujawa K., Dajdok Z. and Grzesiak W. (2011) Species richness and composition of bird communities in various field margins of Poland. Agriculture Ecosystems and Environment 141: 202-209.

WUCZYŃSKI A., DAJDOK Z., WIERZCHOLSKA S. and KuJAwA K. (2014) Applying red lists to the evaluation of agricultural habitat: regular occurrence of threatened birds, vascular plants, and bryophytes in field margins of Poland. Biodiversity and Conservaton 23: 999-1017.

Zechmeister H., Tribsch A., Moser D. and WrbKa T. (2002) Distribution of endangered bryophytes in Austrian agricultural landscapes. Biological Conservation 103: 173-182.

http://worldclim.org [accesed on 5 January 2019]. http://www.mmediu.ro [accesed on 5 January 2019].
Cristian SitAR

Department of Taxonomy and Ecology Babeș-Bolyai University, Clinicilor 5-7 Cluj-Napoca, 400006, Romania Zoological Museum Babeș-Bolyai University, Clinicilor 5-7 Cluj-Napoca, RO-400006, Romania E-mail: cristiansitar@yahoo.com

Geanina Magdalena IACOB Department of Taxonomy and Ecology Babeș-Bolyai University, Clinicilor 5-7 Cluj-Napoca, 400006, Romania E-mail: giacob@yahoo.com

Received: 23.08.2019

Accepted: 04.09.2019

Published online: 31.12.2019

Published: 31.12.2019

Online article number: ER23201902

doi: 10.24193/entomolrom.23.2
Dragomir - Cosmin DAVID Department of Taxonomy and Ecology Babeș-Bolyai University, Clinicilor 5-7 Cluj-Napoca, 400006, Romania E-mail:davidcosmin18@yahoo.com

\author{
Angela Monica IonICă \\ University of Agricultural Sciences and \\ Veterinary Medicine, "Regele Mihai I al \\ României” Life Science Institute, \\ Calea Mănăştur 3-5, \\ Cluj-Napoca, 400372, Romania \\ E-mail: ionica.angela@usamvcluj.ro
}

Iulia MunTEAN

Department of Taxonomy and Ecology

Babeș-Bolyai University, Clinicilor 5-7

Cluj-Napoca, 400006, Romania

E-mail: iulia_hcc@yahoo.com
László RÁKOSY

Department of Taxonomy and Ecology Babeș-Bolyai University, Clinicilor 5-7 Cluj-Napoca, 400006, Romania E-mail: laszlo.rakosy@ubbcluj.ro 